\title{
On the trail of milk bioactive peptides in human and animal intestinal tracts during digestion: A review
}

\author{
Rachel Boutrou • Gwénaële Henry • \\ Laura Sanchez-Rivera
}

Received: 3 June 2014 / Revised: 14 November 2014 / Accepted: 16 December 2014 /

Published online: 28 January 2015

(C) INRA and Springer-Verlag France 2015

\begin{abstract}
Digestion of proteins leads to the release of numerous peptides in the gastrointestinal tract, among them several bioactive peptides. This review compiles, organises and critically analyses the information available on bioactive peptides present in vivo in the digestive tract of adult humans and animals. It focuses on milk proteins, which are recognised as one of the main sources of bioactive peptides with different biological functions. To date, few studies have been performed on the presence of milk-derived peptides in the intestinal tract in vivo. The diversity of these studies is remarkable in terms of the milk products that have been tested, the animal models selected and the segment of the digestive tract considered. Altogether, 69 bioactive peptides identified in vivo are reviewed. Most of them are released from casein, and especially from $\beta$-casein, to which 38 bioactive peptides are attributed. These sequences can be classified mainly as angiotensin-converting enzyme (ACE) inhibitors, opioids and antimicrobial peptides. Particular attention is paid to $\beta$ casomorphins and caseinomacropeptide-derived peptides. The function of caseinophosphopeptides as a mineral carrier is also discussed. Few bioactive peptides derive from whey proteins.
\end{abstract}

Keywords Milk · Bioactive peptides · Intestinal tract $\cdot$ In vivo

\footnotetext{
R. Boutrou $(\bowtie) \cdot G$. Henry

INRA, UMR1253, Science et Technologie du Lait et de l'Euf, 35042 Rennes, France

e-mail: rachel.boutrou@rennes.inra.fr

R. Boutrou $\cdot$ G. Henry

AGROCAMPUS OUEST, UMR1253, Science et Technologie du Lait et de l'CEuf, 35042 Rennes, France

L. Sanchez-Rivera

Instituto de Investigación en Ciencias de la Alimentación, CIAL (CSIC-UAM), C/ Nicolas Cabrera 9, Campus de Cantoblanco de la Universidad Autónoma de Madrid, 28049 Madrid, Spain
} 


\section{Introduction}

Numerous peptides are usually found in the gastrointestinal tract (GIT). Some derive from food-protein digestion while others are released from intestinal cells. Among the food-derived peptides are biologically active peptides, commonly called bioactive peptides. These peptides have been defined as specific protein fragments that have a positive impact on body functions and may ultimately influence health (Kitts and Weiler 2003). Upon oral administration, bioactive peptides may exert an effect on the major body systems, namely the cardiovascular, digestive, immune and nervous systems.

Much effort has been devoted to evaluating in vivo effects produced by milk proteins and/or peptides (Fitzgerald et al. 2004; Jäkälä and Vapaatalo 2010; Phelan and Kerins 2011; Ramabadran and Bansinath 1989; Ricci-Cabello et al. 2012; Rutherfurd-Markwick 2012). These studies considered the ingestion of proteins and peptides and either subsequent health effects or the presence of the bioactive peptide in the blood. Few studies have focused on the presence of bioactive peptides in the digestive tract. However, to understand how food provides health benefits, it is necessary to know how food is processed throughout digestion and/or how the peptides consumed are preserved from the action of digestive enzymes. This review focuses on bioactive peptides that have been identified in the digestive tract of adult humans and animals, since digestion, the first process that ingested food undergoes, determines their formation from food proteins and their fate.

A wide range of food-derived peptides with a variety of physiological functions has been discovered over recent decades. In particular, milk represents one of the main sources of bioactive peptides. Their beneficial health effects may be classified as antimicrobial, antioxidative, antithrombotic, antihypertensive or immunomodulatory (Choi et al. 2012; Korhonen and Pihlanto 2006). In this review, milk-derived bioactive peptides present in vivo in the GIT were considered in order to provide information about their release and stability throughout digestion. The main difficulty in exhaustively collecting these data lies in compiling two kinds of information: the peptides identified in vivo in the GIT and their reported activity. We gathered peptides that are identified as bioactive in the literature and present in the GIT, even if they need to be subsequently absorbed to reach their target. We also discuss the challenge of identifying bioactive peptides within digestive effluents, which are complex mixtures of peptides and many other components.

\section{Diversity of the in vivo studies}

Few studies have been performed on the presence of milk-derived peptides in the GIT in vivo (Table 1). Their diversity is remarkable in terms of the milk products consumed and the segment of the GIT studied, whether in humans or in animals.

The milk products consumed ranged from single molecules to complex dairy matrices. Some examples include purified products, such as a mix of peptides of interest, i.e. phosphopeptides (Brommage et al. 1991; Hirayama et al. 1992; Kasai et al. 1995), caseinomacropeptide (Fosset et al. 2002; Ledoux et al. 1999), a single protein such as lactoferrin (Troost et al. 2001), or milk-protein fractions, i.e. casein and 


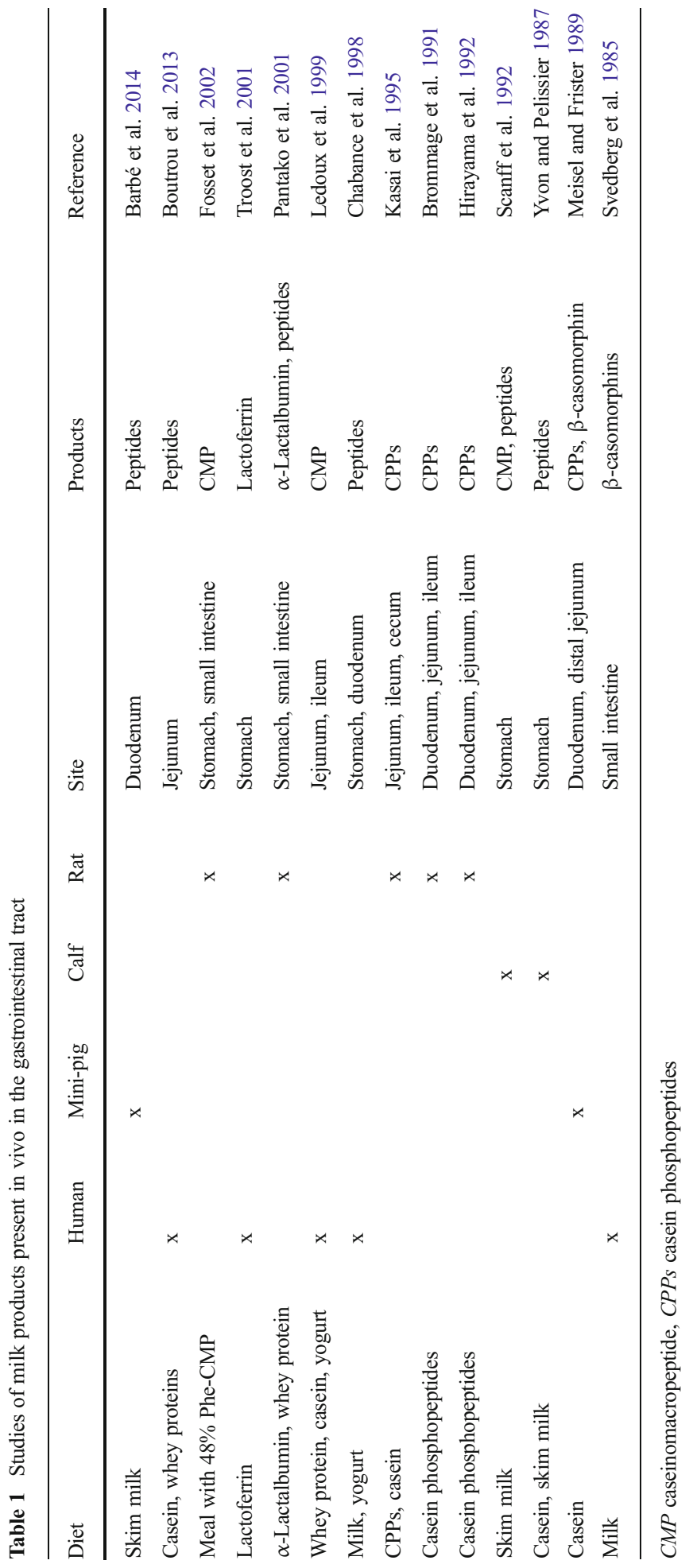


whey proteins (Boutrou et al. 2013; Meisel and Frister 1989). Some information has been gathered on skim milk, which is more complex and consists of several proteins, salts, minerals and vitamins that interact with each other (Chabance et al. 1998; Scanff et al. 1992; Yvon and Pelissier 1987). Raw whole milk, which contains lipids in addition to these components, is an emulsion of fat globules formed within a waterbased fluid (Svedberg et al. 1985). Some reports also exist on in vivo digestion of yogurt, which is fermented milk whose proteins have been degraded by starter bacteria (Chabance et al. 1998; Ledoux et al. 1999). Furthermore, skim milk can be heated and processed to form a gel to evaluate the influence of matrix structure on protein digestion (Barbé et al. 2014). One must consider the impacts of the food matrix (milk versus casein meal, for example) in terms of human nutrition and biological effects (Ross et al. 2013), not just the peptides released. Barbé et al. (2014) aimed to determine the effect of dairy matrix structure on the milk peptidome generated in the gut lumen of mini-pigs after ingestion of raw and heated milk and their corresponding gels. They concluded that matrix structure strongly affects the kinetics of milk-protein digestion, with raw and heated liquid milk having approximately two and three times as many peptides identified as rennet gels, respectively. The number of bioactive peptides identified was a function of the total number of peptides. The number of biopeptides derived from $\beta$ casein in gels decreased most compared to the number in the liquid milks. The authors suggested a higher resistance of rennet gels to hydrolysis; this resistance was not observed in acid gels.

All the animal species used in digestion studies are mammals. Calves act as monogastric animals for the first 2 weeks of life, using only the abomasum to digest milk (Scanff et al. 1992; Yvon and Pelissier 1987). Rodents such as rats can be used in physiological studies of the GIT, but the results are less relevant for digestion studies because the digestive enzymes of rodents are more adapted to a cellulose-based diet (e.g. seeds and grains). In contrast, the pig represents the most relevant model to assess the human digestion process because its enzymes and the physiology of its digestive tract are the closest to those of humans (Deglaire et al. 2009). The diet to be tested can be a determining factor in the choice of the animal model. A calf needs a 5-kg test meal, i.e. milk (Yvon and Pelissier 1987), while mini-pigs need from 0.1 to $1.0 \mathrm{~kg}$ of liquid milk or dairy gels (Barbé et al. 2014) or $100 \mathrm{~g}$ of casein (Meisel and Frister 1989). However, a few $\mathrm{g}$ of purified protein were adequate for a rat meal (Brommage et al. 1991; Kasai et al. 1995). Around $30 \mathrm{~g}$ of casein (Boutrou et al. 2013) or $5 \mathrm{~g}$ of lactoferrin (Troost et al. 2001) was suitable to study their digestion in human.

As for the segment of the GIT studied, the literature describes studies conducted from the stomach to the cecum, involving various digestive enzymes. Pepsin is the main digestive enzyme acting on proteins in the stomach. Proteolytic pancreatic enzymes, i.e. trypsin, chymotrypsin and carboxypeptidases, are delivered to the duodenum and thus are present in the small intestine. Enzymes from gut microbiota can also hydrolyse proteins and peptides, especially in the ileum and colon.

Other factors play a key role in the digestion of milk proteins, such as the hydrolysis rate of proteins through digestion time. Boirie et al. (1997) defined casein and whey protein as slow and fast proteins, respectively.

In addition to the factors cited above, the analysis strategy and the techniques used to detect bioactive peptides within digestive effluents are important issues. The method of analysis applied in these studies has changed in recent decades. Until the 2000s, studies 
mainly dealt with (i) a given bioactive peptide that was detected, and even quantified, using immunological techniques such as ELISA or (ii) a small number of peptides that were identified using liquid chromatography (LC) and Edman degradation to determine the N-terminal amino acid sequence. Since 2010, the use of LC coupled with mass spectrometry (MS) represented a breakthrough and made possible the extensive characterisation of the peptides in digestive effluents. For instance, Boutrou et al. (2013) identified more than 400 peptides from casein and whey proteins in the jejunal content of humans after ingestion of these proteins. Moreover, the use of nanoLC-MS/ MS allowed more concentrated samples to be analysed in an extended separation time than conventional LC-MS/MS. Barbé et al. (2014) detected 2975 sequences in effluents from mini-pigs fed raw milk. Both studies give an overall view of the peptidic profile generated in vivo, in which bioactive peptides were particularly tracked. The application of MS-based techniques on the formation of milk peptides, especially bioactive ones, and their changes throughout digestion has been recently reviewed (Picariello et al. 2013; Sanchez-Rivera et al. 2014).

\section{Bioactive peptides generated in the digestive tract through in vivo digestion of milk proteins}

\subsection{Bioactive peptides from $\beta$-casein}

Some bioactive peptides from $\beta$-casein (38) have been observed within the GIT in adult animals and humans fed milk products (Table 2). Diverse biological activities have been attributed to these $\beta$-casein sequences. The most frequent are angiotensin-converting enzyme (ACE)-inhibitory peptides (22), which originate from different regions of the entire sequence of the protein. ACE is one of the key enzymes implicated in the regulation of blood pressure, and its inhibition represents one well-known mechanism of action for milk-derived peptides (Phelan and Kerins 2011). In addition, several peptides with other reported activities have been found in digestive effluents in vivo. For instance, ten opioid peptides originate mainly from the region 59-80, and four immunomodulatory peptides originate from the C-terminal end. Noteworthy is the similarity displayed by two of the three antioxidant peptides: $\beta$-casein(169-176) has only one more amino acid residue than $\beta$-casein(170-176). Considering the three inhibitors of proteolytic enzymes, one of the sequences, $\beta$-casein(59-67) is included in the other, $\beta$-casein(58-72). These observations question the minimal active sequence required for a peptide to exert a physiological function in vivo.

Particular attention has focused on $\beta$-casomorphins $(\beta-\mathrm{CM})$, opioid-like peptides that behave like a $\mu$-type opioid agonist. They consist of fragments from the $\beta$-casein sequence 60-70 (YPFPGPIPNSL), such as YPFPGPI ( $\beta-\mathrm{CM} 7)$ or even shorter fragments from the $\mathrm{C}$-terminal portion, i.e. $\beta$-CM $6, \beta-\mathrm{CM} 5$ and $\beta$-CM 4 . The first in vivo demonstration of the presence of $\beta-\mathrm{CM}$ immunoreactive material in intestinal effluents of humans fed raw milk was reported by Svedberg et al. (1985). Although they detected $\beta$-CM 7 in duodenal effluents, chromatographical characterisation showed that most of the immunoreactive material was larger than $\beta-\mathrm{CM} 7$, meaning that it might have been a precursor. This hypothesis was verified in the duodenal chyme 


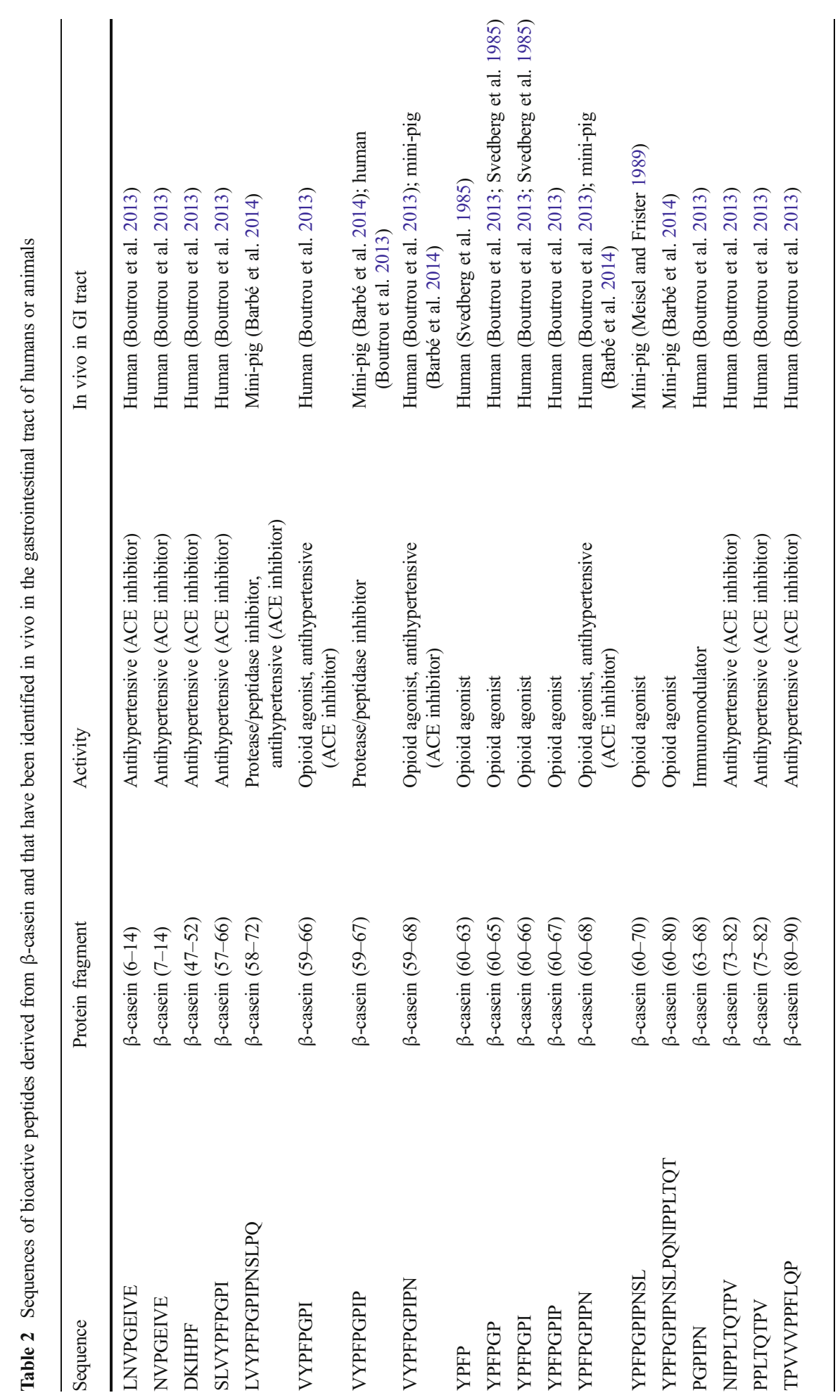

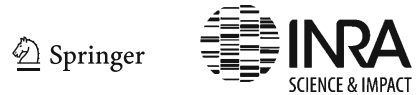




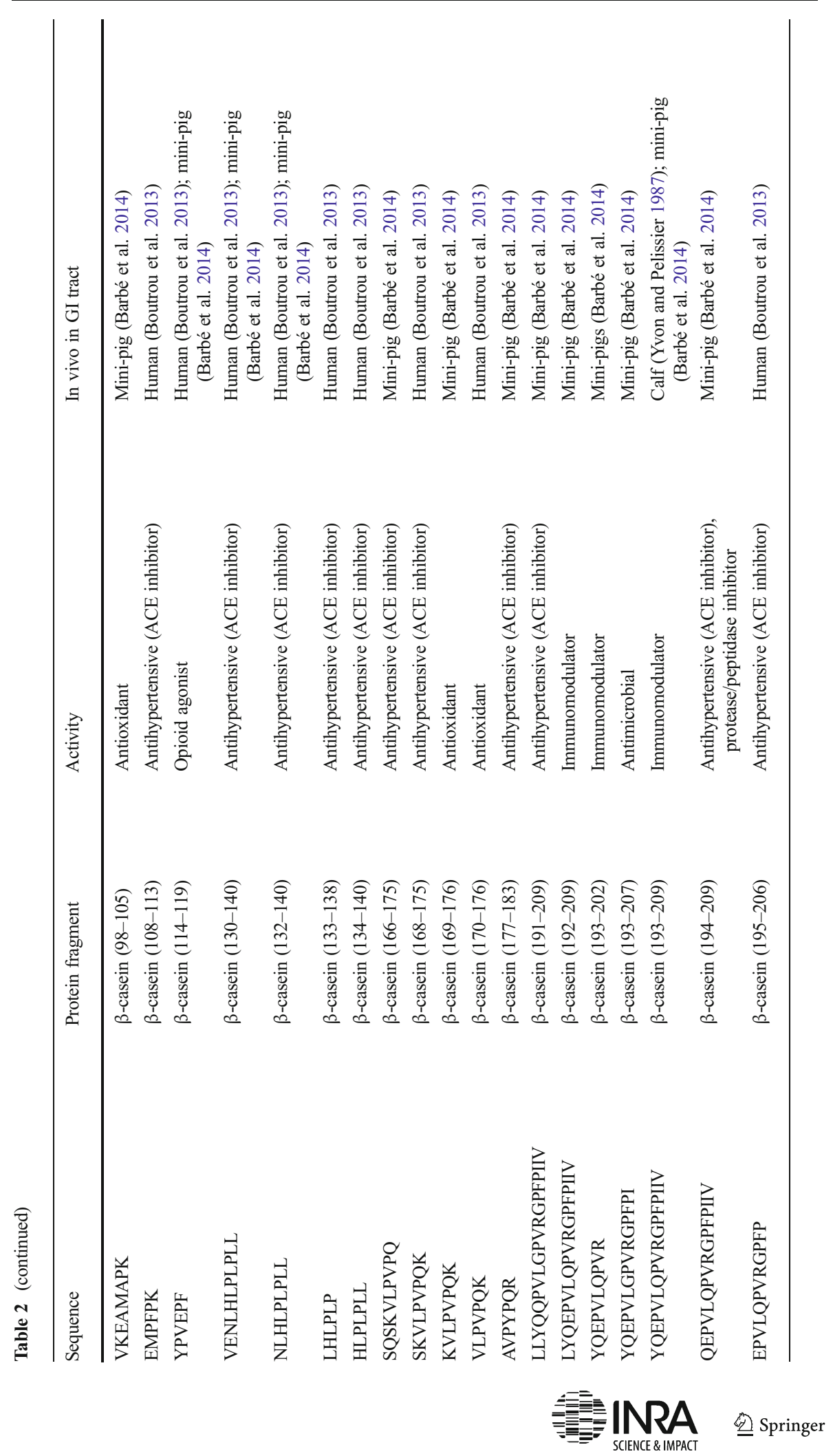


of mini-pigs fed casein, in which $\beta$-CM 11 was the main $\beta$-CM present (Meisel and Frister 1989). In the human jejunum, $\beta$-CMs were the most frequently identified bioactive peptides during $6 \mathrm{~h}$ of digestion after casein ingestion, while $\beta-\mathrm{CM} 11$ was not identified using MS (Boutrou et al. 2013). Altogether, these results suggest the presence of $\beta$-CM precursors in the duodenum and that of $\beta-\mathrm{CMs}$ only in the jejunum, where they can bind opioid receptors.

\subsection{Bioactive peptides from $\alpha_{\mathrm{s} 1^{-}}, \alpha_{\mathrm{s} 2^{-}}$and $\mathrm{k}$-caseins}

Bioactive peptides from $\alpha_{\mathrm{s} 1^{-}}, \alpha_{\mathrm{s} 2^{-}}$and $\mathrm{K}$-caseins (18, seven and six peptides, respectively) have been identified in the GIT in vivo (Table 3). Among them, 13 antihypertensive peptides from $\alpha_{\mathrm{s} 1}$-casein (nine peptides), $\alpha_{\mathrm{s} 2}$-casein (two peptides) and $\mathrm{k}$-casein (two peptides) have been reviewed. In addition, seven antimicrobial peptides have been reported, including three peptides from the region 175207 of $\alpha_{\mathrm{s} 2}$-casein. The other 11 bioactive peptides have diverse activities: antioxidant, opioid, antistress, antithrombotic, protease and peptidase inhibitor, and phosphodiesterase inhibitor. We find only one immunomodulator peptide in vivo in the GIT.

\subsection{Caseinomacropeptide within in vivo digests}

The release of caseinomacropeptide (CMP) during milk-protein digestion in the intestine could be of nutritional and physiological significance since this peptide has been shown to have various biological activities as regulatory compounds, either directly as a neurotransmitter or indirectly by modulating the secretion of intestinal hormones (Thoma-Worringer et al. 2006). CMP in the intestine has an inhibitory effect on gastric acid secretion and stimulates pancreatic secretion through the release of cholecystokinin, although no effect on satiety could be demonstrated. CMP can modulate the cardiovascular system through its antithrombotic and antihypertensive activities. It has also been shown that CMP can exert immunomodulating and antimicrobial effects by inhibiting pathogen adhesion to cells, as well as influenza viruses.

Digestion of CMP was widely studied in the 1990s. It is a 64-amino acid peptide released from $\mathrm{K}$-casein during the first phase of digestion through the action of gastric enzymes, which rapidly cleaves the peptide bond $\mathrm{Phe}_{105}-\mathrm{Met}_{106}$ and produces an Nterminal fragment (para-K-casein, residue 1-105) and CMP (residue 106-169). CMP is a predominant breakdown product in the stomach of humans (Ledoux et al. 1999) and calves (Yvon and Pelissier 1987) after ingestion of casein, skim milk or yogurt. It is detected in stomach contents during the first few hours of digestion; thus, it resists the action of gastric enzymes. Chabance et al. (1998) also identified the antithrombotic peptide $\mathrm{K}$-casein(106-116) in human gastric samples from 20 min to $4 \mathrm{~h}$ after milk ingestion. In vivo studies have demonstrated that most intact CMP is rapidly released in the stomach (Fosset et al. 2002; Ledoux et al. 1999). CMP is thus present in the human duodenum and jejunum following casein and yogurt ingestion (Chabance et al. 1998; Ledoux et al. 1999). Thereafter, it undergoes partial hydrolysis by pancreatic enzymes to an extent that depends on its transit rate in the lumen (Ledoux et al. 1999). Some derived fragments are also present in the proximal and median intestine of rats fed Phe- 


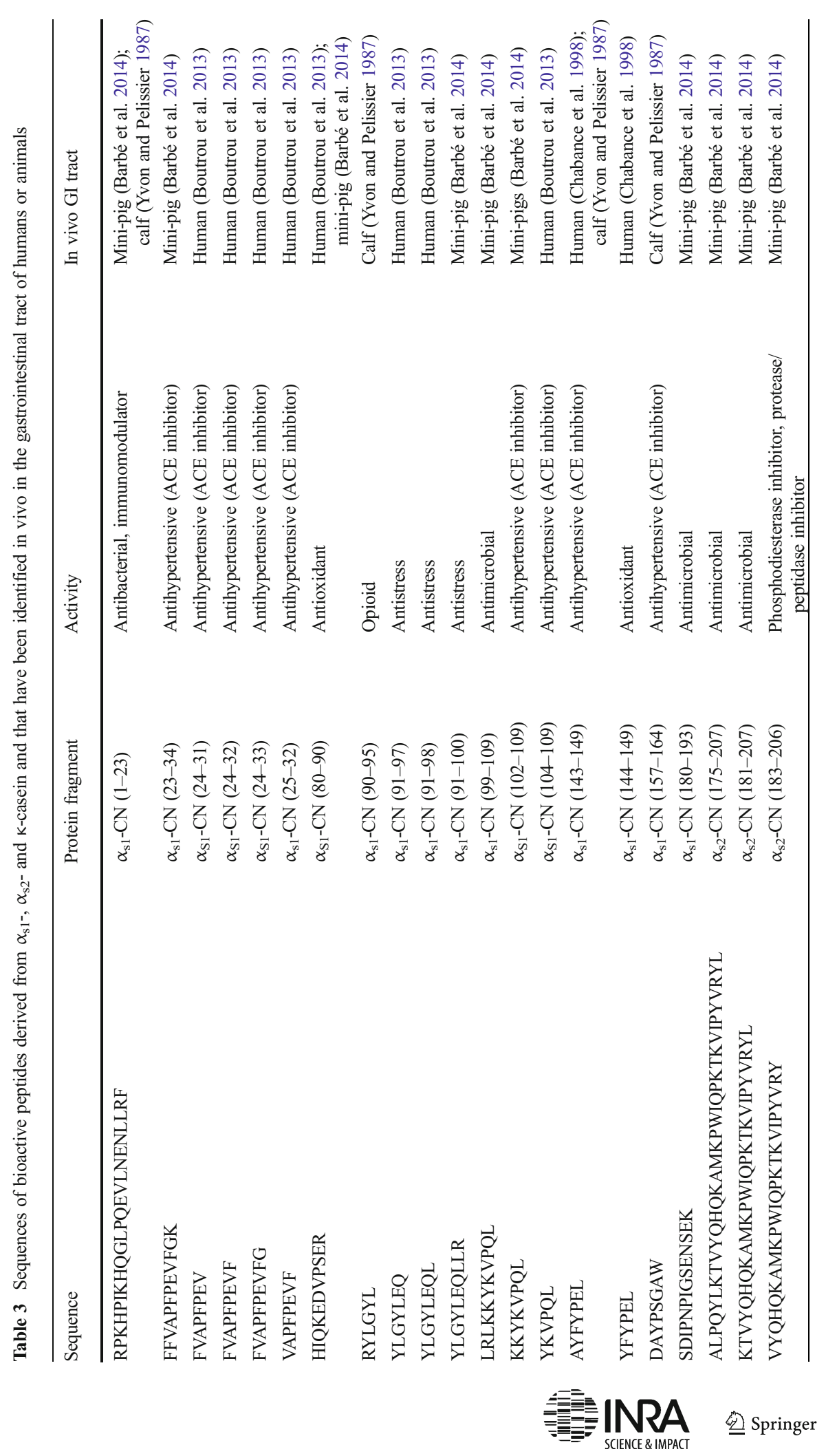




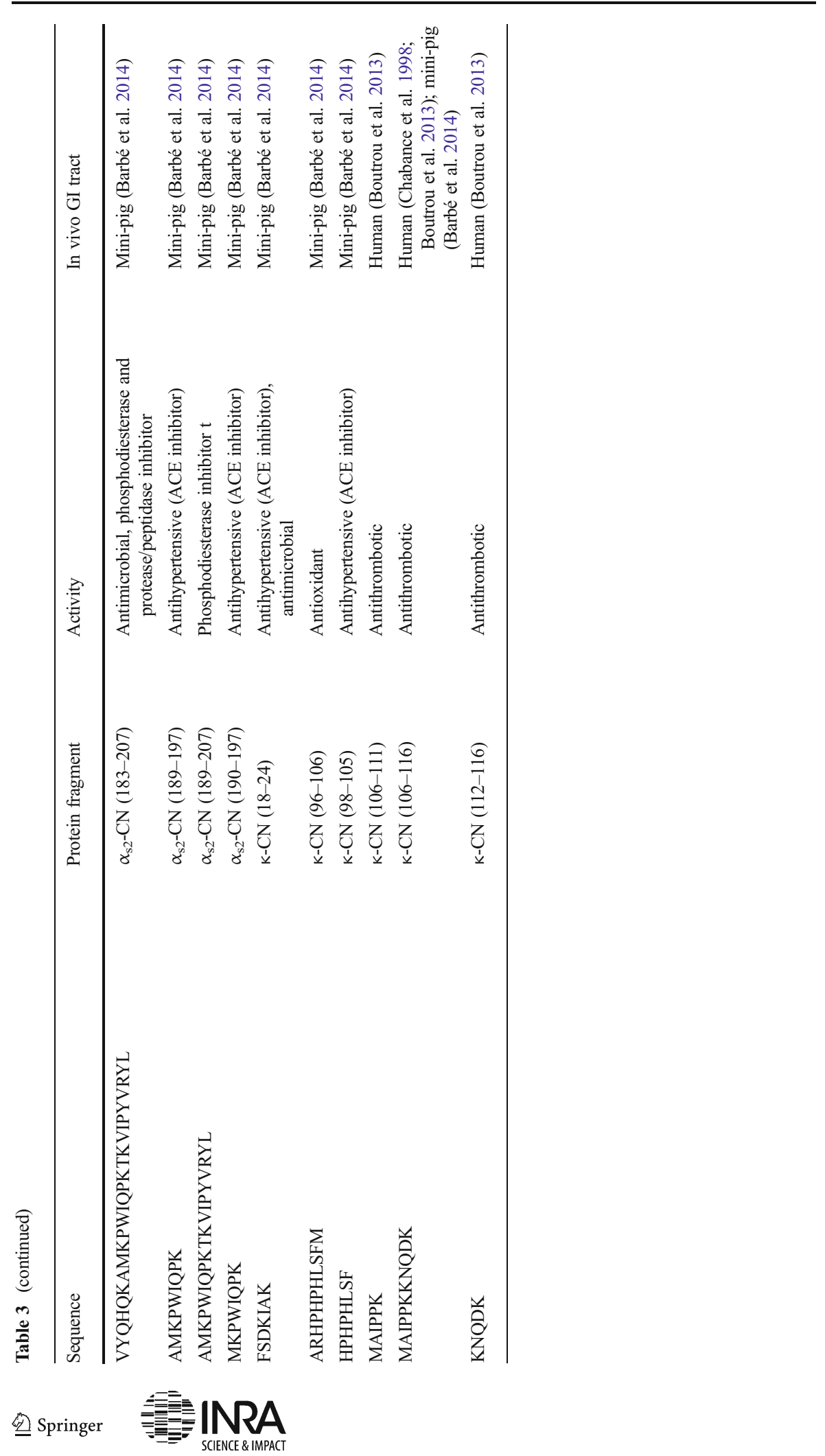


CMP, but none is bioactive; nonetheless, it is notable that two of them contain the antithrombotic sequence K-casein(112-116) (Fosset et al. 2002). Both K-casein(112116) and the aforementioned $\mathrm{K}$-casein(106-116) have been identified in the human intestine (Boutrou et al. 2013).

\subsection{Caseinophosphopeptides identified in the GIT in vivo}

Milk's high calcium availability has been attributed to caseinophosphopeptides (CPPs) formed during digestion of casein in the small intestine. CPPs have been described as mineral carriers because of the phosphorylated serine residues in their sequence that bind minerals such as calcium, iron and zinc and thus play an important role in mineral bioavailability by forming soluble complexes that prevent, for example, calcium phosphate from precipitating (Ait-Oukhatar et al. 2002; Sato et al. 1991). Kasai et al. (1995) reported CPPs in the digestive tract of rats fed casein, from the stomach to the colon. They also estimated that the residual CPPs of rats fed casein are not distinguishable from those of rats fed a CPP diet. The large CPP $\alpha_{\mathrm{s} 1}$-casein(110-142) was found in gastric effluents of calves after ingestion of skim milk (Scanff et al. 1992). In vivo formation of CPP $\alpha_{\mathrm{s} 1}$-casein(66-74) was demonstrated in the distal jejunum of cannulated mini-pigs fed casein (Meisel and Frister 1989). The most abundant CPPs from $\alpha_{\mathrm{s} 1}$-casein present in the ileum of rats when CPPs were ingested were the peptides $\alpha_{\mathrm{s} 1}$ casein(61-74) (Hirayama et al. 1992) and $\alpha_{\mathrm{s} 1}$-casein(59-79) (Brommage et al. 1991). Regarding CPPs from $\beta$-casein present in the ileum of rats fed CPPs, the following have been reported: $\beta$-casein(1-25), $\beta$-casein(1-28), $\beta$-casein(33-48) (Brommage et al. 1991) and $\beta$-casein(7-24) (Hirayama et al. 1992). Overall, in these studies, CPPs were determined according to the phosphorylation of amino acids in soluble fractions prepared from digestive effluents. In studies whose strategy was to track bioactive peptides within an entire profile of peptides identified by MS, sequences, but not always their degree of phosphorylation, was considered. For CPPs, the presence of the complete phosphorylated seryl-cluster $(\mathrm{SpSpSpEE})$ in the sequence has been described as the main factor influencing their interaction with minerals, although the surrounding residues or the length of the sequence may also have an influence (Cross et al. 2005; Reynolds et al. 1994). Barbé et al. (2014) identified almost 150 CPPs in vivo at different times of digestion in duodenal effluents of mini-pigs fed a variety of dairy products. Most were either mono- or diphosphorylated; Table 4 presents the most frequently identified CPPs. It is important to note that some of the CPPs identified in vivo might be considered mineral carriers due to the presence of phosphoseryl residues in their sequences, whereas their bioactivity has not been experimentally established. Furthermore, some CPPs have been demonstrated to be active when administered individually, while others are active when present in a mixture of CPPs (Ait-Oukhatar et al. 2002). This reinforces the difficulty in identifying active CPPs within digestive effluents.

\subsection{Identification of bioactive peptides by MS}

It is difficult to identify all peptides in a digestive effluent with a single type MS analysis because all ranges of molecular weights (from entire proteins to dipeptides) cannot be screened (Panchaud et al. 2012). C18 reversed-phase LC is the most common 
Table 4 CPPs derived from caseins that have been identified in vivo in the gastrointestinal tract of mini-pigs (data collected from Barbé et al. 2014)

\begin{tabular}{|c|c|c|c|c|}
\hline $\begin{array}{l}\text { Number of } \\
\text { phosphorylated } \\
\text { sites }\end{array}$ & Sequence & $\begin{array}{l}\text { Protein fragment } \\
\text { incriminated }\end{array}$ & $\begin{array}{l}\text { Numbers of } \\
\text { identified CPP }\end{array}$ & $\begin{array}{l}\text { Some of the most frequently } \\
\text { identified CPP }\end{array}$ \\
\hline \multirow[t]{4}{*}{3} & \multirow[t]{4}{*}{ SpSpSpEE } & $\beta-\mathrm{CN}(17-21)$ & 4 & \multirow{4}{*}{$\begin{array}{l}\beta-\mathrm{CN}(1-24), \beta-\mathrm{CN}(1-29), \\
\quad \beta-\mathrm{CN}(6-25) \\
\alpha_{\mathrm{s} 2}-\mathrm{CN}(1-24)\end{array}$} \\
\hline & & $\alpha_{\mathrm{s} 1}-\mathrm{CN}(66-70)$ & 0 & \\
\hline & & $\alpha_{\mathrm{s} 2}-\mathrm{CN}(8-12)$ & 4 & \\
\hline & & $\alpha_{\mathrm{s} 2}-\mathrm{CN}(56-60)$ & 0 & \\
\hline 2 & SpTSpEE & $\alpha_{\mathrm{s} 2}-\mathrm{CN}(129-133)$ & 7 & $\begin{array}{l}\alpha_{\mathrm{s} 2}-\mathrm{CN}(124-137), \alpha_{\mathrm{s} 2}-\mathrm{CN} \\
\quad(124-140), \alpha_{\mathrm{s} 2}-\mathrm{CN}(124-142), \\
\quad \alpha_{\mathrm{s} 2}-\mathrm{CN}(124-146)\end{array}$ \\
\hline 2 & SpESpTE & $\alpha_{\mathrm{s} 1}-\mathrm{CN}(46-50)$ & 25 & $\begin{array}{l}\alpha_{\mathrm{s} 1}-\mathrm{CN}(40-52), \alpha_{\mathrm{s} 1}-\mathrm{CN}(40-58), \\
\alpha_{\mathrm{s} 1}-\mathrm{CN}(40-61), \alpha_{\mathrm{s} 1}-\mathrm{CN} \\
(40-63), \alpha_{\mathrm{s} 1}-\mathrm{CN}(43-58)\end{array}$ \\
\hline 1 & SpEE & $\beta-\mathrm{CN}(35-37)$ & 51 & $\begin{array}{l}\beta-\mathrm{CN}(29-44), \beta-\mathrm{CN}(29-45), \\
\beta-\mathrm{CN}(30-52), \beta-\mathrm{CN}(33-48)^{\mathrm{a}}, \\
\beta-\mathrm{CN}(33-52)\end{array}$ \\
\hline 1 & SpTE & $\alpha_{\mathrm{s} 2}-\mathrm{CN}(143-145)$ & 11 & $\begin{array}{l}\alpha_{\mathrm{s} 2}-\mathrm{CN}(138-149), \alpha_{\mathrm{s} 2}-\mathrm{CN} \\
\quad(138-150)\end{array}$ \\
\hline 1 & SpAEE & $\alpha_{\mathrm{s} 1}-\mathrm{CN}(115-118)$ & 45 & $\begin{array}{l}\alpha_{\mathrm{s} 1}-\mathrm{CN}(109-119)^{\mathrm{a}}, \alpha_{\mathrm{s} 1}-\mathrm{CN} \\
\quad(110-119), \alpha_{\mathrm{s} 1}-\mathrm{CN}(110-120)^{\mathrm{a}}, \\
\alpha_{\mathrm{s} 1}-\mathrm{CN}(110-124)\end{array}$ \\
\hline
\end{tabular}

$\mathrm{Sp}=$ phospho-serine

${ }^{a}$ Also identified in humans (Boutrou et al. 2013)

method used to separate peptides before their characterisation by MS. However, small peptides containing some hydrophobic amino acids are not retained in C18 columns (Panchaud et al. 2012). In addition, peptides composed of less than six amino acids are not usually addressed using MS because it is difficult to unambiguously infer them back to one precursor protein. For very small peptides such as di- and tripeptides, separation is required prior to injection into the mass spectrometer (Panchaud et al. 2012). For example, the ACE-inhibitory peptides Ile-Pro-Pro (IPP), Leu-Pro-Pro (LPP), AW, IW, LW, VY, IY and FY were identified in plasma of humans fed a peptide-enriched milk using a LC-multiple reaction ion monitoring-MS (LC-MRMMS) method (Foltz et al. 2007). The authors assessed the bioavailability of IPP and seven other ACE-inhibitory peptides present in a lactotripeptide-enriched yogurt beverage to determine whether meal intake affects IPP bioavailability in humans. They concluded that the tripeptide IPP selectively escapes from intestinal degradation and reaches the blood circulation undegraded. Similarly, IPP, LPP and VPP were intragastrically administered to pigs and reached blood circulation in an intact form (van der Pijl et al. 2008). Meta-analyses on the effect of lactotripeptides on blood pressure in humans also exist (Pripp 2008; Qin et al. 2013). However, to our knowledge, there is no evidence for the identification of di- and tripeptides in vivo in the GIT.

Considering the currently identified bioactive peptides from casein (Tables 2 and 3), the smallest is $\beta-\mathrm{CM} 4$, with four amino acids; it was detected as an immunoreactive material by Svedberg et al. (1985). Sixty-seven bioactive peptides identified in vivo in 
the GIT (Tables 2 and 3) contain more than five amino acids. Focusing on bioactive peptides from casein composed of more than five amino acids, 129 and 126 peptides are referenced in our research unit homemade database and in the BIOPEP database (http://www.uwm.edu.pl/biochemia/index.php/pl/biopep), respectively. Two assumptions explain why almost half of the reported bioactive peptides are not identified in vivo in the GIT, each with completely different consequences from a nutritional viewpoint: either the region of the protein where the peptide is encrypted was almost completely digested, leading to a negligible concentration of the bioactive peptide, or the bioactive peptides were too large for efficient identification by MS in digestive effluents (Boutrou et al. 2013; Ross et al. 2013).

\subsection{Bioactive peptides released from whey proteins in vivo}

According to databases, a hundred or so bioactive peptides are encrypted in milk whey proteins; however, few have been identified in digestive effluents in vivo. Whey proteins are relatively resistant to peptic digestion, especially $\beta$-lactoglobulin $(\beta$-Lg), due to its particular folding (Dalgalarrondo et al. 1995). Troost et al. (2001) studied human gastric digestion of lactoferrin, an iron-binding protein that favours iron absorption and also displays antioxidative, anti-inflammatory, immunomodulatory and antimicrobial activities (Garcia-Montoya et al. 2012). They concluded that more than $65 \%$ of lactoferrin survives gastric transit. Using gel permeation chromatography, they found several lactoferrin fragments of different sizes throughout digestion. The most abundant fragments had molecular weights of 76 and $41 \mathrm{kDa}$ and were able to bind the antibodies against intact lactoferrin. Pantako et al. (2001) studied the effect of digestion on dry matter recovery and peptide distribution in the gastrointestinal content of rats fed $\alpha$-lactalbumin, a metalloprotein that strongly binds calcium and zinc ions and has bactericidal or antitumor activity. Their results indicated that $\alpha$-lactalbumin rapidly left the stomach and was quickly digested into amino acids and absorbed in the proximal small intestine. It would be interesting to study in vivo the digestion of an $\alpha$-lactalbumin/oleic acid complex, which has been reported to induce the selective death of tumour cells (Brück et al. 2014).

Recently, certain bioactive peptides from whey proteins were identified in digestive effluents using MS. Only three bioactive peptides derived from $\beta$-Lg were identified in duodenal effluents of mini-pigs fed raw milk (Barbé et al. 2014): two antihypertensive sequences, i.e. $\beta-\operatorname{Lg}(32-40)$ and $\beta-\operatorname{Lg}(142-148)$, and the antimicrobial peptide $\beta$ $\operatorname{Lg}(92-100)$. The latter peptide was not detected in jejunal effluents from humans fed whey proteins. Instead, various related fragments were identified, such as $\beta-\operatorname{Lg}(92-98)$, (92-99), (92-103) and (93-100) (Boutrou et al. 2013). Whether these sequences exert any biological activity deserves further investigation. Indeed, some peptides not identified as bioactive can act in situ in the GIT. Further research on the interaction of peptides with intestinal receptors would constitute a prospective strategy on this topic. Among food-derived peptides identified in the GIT, it is also important to note that some may interact in situ with receptors located in the gut. Bioactive peptides that regulate gastrointestinal function and intake have been described (Froetschel 1996; Shimizu and Ok Son 2007), and some of them were detected in digestive effluents, such as CPPs that enhance mineral absorption and opioid peptides that regulate intestinal motility (Shimizu and Ok Son 2007). 


\section{Conclusion}

This review collected comprehensive data that provides valuable information for (i) understanding physico-chemical parameters of protein digestion (for instance, peptides identified in vivo are important data for correlating the in vitro tools necessary to develop models that mimic protein digestion), (ii) improving protein-design or dietstructure approaches to optimise the release of bioactive peptides and (iii) shedding light on nutrient bioaccessibility (i.e. the percentage of a nutrient digested and released from the food matrix in its absorbable form).

Acknowledgments The authors are involved in the Food and Agriculture COST (European Cooperation in Science and Technology) Action FA1005 "Improving health properties of food by sharing our knowledge on the digestive process" (INFOGEST).

Conflict of interest Rachel Boutrou, Gwénaële Henry and Laura Sanchez-Rivera declare that they have no conflicts of interest.

\section{References}

Ait-Oukhatar N, Peres JM, Bouhallab S, Neuville D, Bureau F, Bouvard G, Arhan P, Bouglé D (2002) Bioavailability of caseinophosphopeptide-bound iron. J Lab Clin Med 140:290-294

Barbé F, Le Feunteun S, Rémond D, Ménard O, Jardin J, Henry G, Laroche B, Dupont D (2014) Tracking the in vivo release of bioactive peptides in the gut during digestion: mass spectrometry peptidomic characterization of effluents collected in the gut of dairy matrices fed mini-pigs. Food Res Int 63(Part B):147156

Boirie Y, Dangin M, Gachon P, Vasson MP, Maubois JL, Beaufrere B (1997) Slow and fast dietary proteins differently modulate postprandial protein accretion. Proc Natl Acad Sci 94:14930-14935

Boutrou R, Gaudichon C, Dupont D, Jardin J, Airinei G, Marsset-Baglieri A, Benamouzig R, Tomé D, Léonil $J$ (2013) Sequential release of milk protein-derived bioactive peptides in the jejunum in healthy humans. Am J Clin Nutr 19:1314-1323

Brommage R, Juillerat MA, Jost R (1991) Influence of casein phosphopeptides and lactulose on intestinal calcium absorption in adult female rats. Lait 71:173-180

Brück WM, Gibson GR, Brück TB (2014) The effect of proteolysis on the induction of cell death by monomeric alpha-lactalbumin. Biochimie 97:138-143

Chabance B, Marteau P, Rambaud JC, Migliore-Samour D, Boynard M, Perrotin P, Guillet R, Jolles P, Fiat AM (1998) Casein peptide release and passage to the blood in humans during digestion of milk or yogurt. Biochimie 80:155-165

Choi J, Sabikhi L, Hassan A, Anand S (2012) Bioactive peptides in dairy products. Int J Dairy Technol 65:1-12

Cross KJ, Huq NL, Palamara JE, Perich JW, Reynolds EC (2005) Physicochemical characterization of casein phosphopeptide-amorphous calcium phosphate nanocomplexes. J Biol Chem 280:15362-15369

Dalgalarrondo M, Dufour E, Chobert JM, Bertrand-Harb C, Haertlé T (1995) Proteolysis of $\beta$-lactoglobulin and $\beta$-casein by pepsin in ethanolic media. Int Dairy J 5:1-14

Deglaire A, Bos C, Tome D, Moughan PJ (2009) Ileal digestibility of dietary protein in the growing pig and adult human. Br J Nutr 102:1752-1759

Fitzgerald RJ, Murray BA, Walsh DJ (2004) Hypotensive peptides from milk proteins. J Nutr 134:980S-988S

Foltz M, Meynen EE, Bianco V, van Platerink C, Koning TMMG, Kloek J (2007) Angiotensin converting enzyme inhibitory peptides from a lactotripeptide-enriched milk beverage are absorbed intact into the circulation. J Nutr 137:953-958

Fosset S, Fromentin G, Gietzen DWU, Dubarry M, Huneau JF, Antoine J, Lang V, Mathieu-Casseron F, Tome D (2002) Peptide fragments released from Phe-caseinomacropeptide in vivo in the rat. Peptides 23:1773-1781

Froetschel MA (1996) Bioactive peptides in digesta that regulate gastrointestinal function and intake. J Anim Sci 74:2500-2508 
Garcia-Montoya IA, Cendon TS, Arévalo-Gallegos S, Rascon-Cruz Q (2012) Lactoferrin a multiple bioactive protein: an overview. Biochim Biophys Acta Gen Subj 1820:226-236

Hirayama M, Toyota K, Hidaka H, Naito H (1992) Phosphopeptides in rat intestinal digests after ingestion casein phosphopeptides. Biosci Biotechnol Biochem 56:1128-1129

Jäkälä P, Vapaatalo H (2010) Antihypertensive peptides from milk proteins. Pharmaceuticals 3:251-272

Kasai T, Iwasaki R, Tanaka M, Kiriyama S (1995) Caseinphosphopeptide (CPP) in feces and contents in digestive tract of rats fed casein and CPP preparations. Biosci Biotechnol Biochem 59:26-30

Kitts DD, Weiler K (2003) Bioactive proteins and peptides from food sources. Applications of bioprocesses used in isolation and recovery. Curr Pharm Des 9:1309-1323

Korhonen H, Pihlanto A (2006) Bioactive peptides: production and functionality. Int Dairy J 16:945-960

Ledoux N, Mahé S, Dubarry M, Bourras M, Benamouzig R, Tomé D (1999) Intraluminal immunoreactive caseinomacropeptide after milk protein ingestion in humans. Nahrung/Food 43:196-200

Meisel H, Frister H (1989) Chemical characterization of bioactive peptides from in vivo digests of casein. J Dairy Res 56:343-349

Panchaud A, Affolter M, Kussmann M (2012) Mass spectrometry for nutritional peptidomics: how to analyze food bioactives and their health effects. J Proteome 75:3546-3559

Pantako OT, Lemieux L, Amiot J (2001) The effects of alpha-lactabumin and whey protein concentrate on dry matter recovery, TCA soluble protein levels, and peptide distribution in the rat gastrointestinal tract. Can J Physiol Pharmacol 79:320-328

Phelan M, Kerins D (2011) The potential role of milk-derived peptides in cardiovascular disease. Food Funct 2:153-167

Picariello G, Mamone G, Nitride C, Addeo F, Ferranti P (2013) Protein digestomics: integrated platforms to study food-protein digestion and derived functional and active peptides. Trac-Trends Anal Chem 52:120134

Pripp AH (2008) Effect of peptides derived from food proteins on blood pressure: a meta-analysis of randomised controlled trials. Food Nutr Res 52:8p

Qin LQ, Xu JY, Dong JY, Zhao Y, van Bladeren P, Zhang W (2013) Lactotripeptides intake and blood pressure management: a meta-analysis of randomised controlled clinical trials. Nutr Metab Carbiovasc Dis 23: 395-402

Ramabadran K, Bansinath M (1989) Pharmacology of beta-casomorphins, opioid peptides derived from milk protein. Asia Pac J Pharmacol 4:45-58

Reynolds EC, Riley PF, Adamson NJ (1994) A selective precipitation purification procedure for multiple phosphoseryl-containing peptides and methods for their identification. Anal Biochem 217:277-284

Ricci-Cabello I, Olalla Herrera M, Artacho R (2012) Possible role of milk-derived bioactive peptides in the treatment and prevention of metabolic syndrome. Nutr Rev 70:241-255

Ross RP, Fitzgerald GF, Stanton C (2013) Unraveling the digestion of milk protein. Am J Clin Nutr 97:11611162

Rutherfurd-Markwick KJ (2012) Food proteins as a source of bioactive peptides with diverse functions. Br J Nutr 108:S149-S157

Sanchez-Rivera L, Martinez-Maqueda D, Cruz-Huerta E, Miralles B, Recio I (2014) Peptidomics for discovery, bioavailability and monitoring of dairy bioactive peptides. Food Res Int 63(Part B):170-181

Sato R, Shindo M, Gunshin H, Noguchi T, Naito H (1991) Characterization of phosphopeptide derived from bovine beta casein: an inhibitor to intra-intestinal precipitation of calcium phosphate. Biochim Biophys Acta 1077:413-415

Scanff P, Yvon M, Thirouin S, Pelissier JP (1992) Characterization and kinetics of gastric emptying of peptides derived from milk proteins in the preruminant calf. J Dairy Res 59:437-447

Shimizu M, Ok Son D (2007) Food-derived peptides and intestinal functions. Curr Pharm Des 13:885-895

Svedberg J, de Haas J, Leimenstoll G, Paul F, Teschemacher H (1985) Demonstration of [beta]-casomorphin immunoreactive materials in in vitro digests of bovine milk and in small intestine contents after bovine milk ingestion in adult humans. Peptides 6:825-830

Thoma-Worringer C, Sorensen J, Lopez-fandino R (2006) Health effects and technological features of caseinomacropeptide. Int Dairy J 16:1324-1333

Troost FJ, Steijns J, Saris WHM, Brummer RJ (2001) Gastric digestion of bovine lactoferrin in vivo in adults. J Nutr 131:2101-2104

van der Pijl PC, Kies AK, Ten Have GAM, Duchateau GSMJ, Deutz NEP (2008) Pharmacokinetics of proline-rich tripeptides in the pig. Peptides 29:2196-2202

Yvon M, Pelissier JP (1987) Characterization and kinetics of evacuation of peptides resulting from casein hydrolysis in the stomach of the calf. J Agric Food Chem 35:148-156 